\title{
Selective Leaching of Steel Pollutant Element from Dilband Iron Ore, Pakistan
}

\author{
INAMULLAH MAITLO*, UMAIR AFTAB*, MUHAMMAD ISHAQUE ABRO**, AND \\ MUHAMMAD MOAZAM BALOCH**
}

RECEIVED ON 20.01.2017 ACCEPTED ON 29.05.2017

\begin{abstract}
Dilband Iron ore of Pakistan is lean grade ore which contains sufficient amount of phosphorous bearing mineral called fluorapatite. Since phosphorous is widely acknowledged as steel pollutant and disturbs the blast furnace chemistry, so it needs to be removed effectively from the ore before the smelting operation. Present paper, therefore, aims to provide the results of phosphorous leaching efficiency noted with $\mathrm{HCl}, \mathrm{HNO}_{3}$ and $\mathrm{H}_{2} \mathrm{SO}_{4}$ reagents. Results showed that $\mathrm{H}_{2} \mathrm{SO}_{4}$ leached the phosphorous quite selectively as compared to $\mathrm{HCl}$ and $\mathrm{HNO}_{3}$. Henceforth, it was possible to eradicate 49.5, 55.6 and 82.2\% $\mathrm{P}_{2} \mathrm{O}_{5}$ from $-600+212,-212+106$, and $-106 \mu \mathrm{m}$ particle size fractions respectively with $1 \%$ concentrated $\mathrm{H}_{2} \mathrm{SO}_{4}$. The gradual increasing trend of dephosphorization with decreasing the particle size implies that, in finer size fraction liberation of fluorapatite mineral was amplified. Perforation study using SEM (Scanning Electron Microscope) provided supporting evidence in this regard.
\end{abstract}

Key Words: Selective Leaching, Fluorapatite, Calcite, Kaolinite, Quartz, Hematite, Scanning Electron Microscope.

\section{INTRODUCTION}

$\mathrm{P}$ SM (Pakistan Steel Mill) is totally dependent on the imported ores because of the lacking of mineral processing activates in the country, concomitantly PSM in now a days is under major financial crises and is reached to the verge of collapse. It is, therefore, imperative to start the ore beneficiation activities so that nation can took full advantage from indigenous ore deposits. Among the iron ore deposits discovered so far in Pakistan, Dilband iron ore is more suitable than any other indigenous ores, because deposits are present in large quantity and of open mine type. Estimated amount of Dilband iron ore is 200 million tons and averagely it is composed of $46.27 \%$ hematite, $17.41 \%$ quartz, $14.47 \%$ calcite, $9.24 \%$ chlinochlore, $10.5 \%$ kaolinite and $1.75 \%$ fluorapatite [1-3]. The dilemma of Dilband iron ore is that it contains two major gangue minerals namely quartz and fluorapatite. Former is fuel consumer in smelting process and latter is major source of phosphorous which is generally believed to be steel pollutant deteriorating ductility of the steel products. Previous work done on this ore indicated that it is almost impossible to upgrade it by any physical separation method, since interlocking of these gangue minerals within the iron matrix is extended up to 5 micron mesh size [4]. Henceforth, the only way

* Department of Metallurgy \& Materials Engineering, Dawood University of Engineering \& Technology, Karachi.

** Department of Metallurgy \& Materials Engineering, Mehran University of Engineering \& Technology, Jamshoro

Mehran University Research Journal of Engineering \& Technology, Volume 36, No. 3, July, 2017 [p-ISSN: 0254-7821, e-ISSN: 2413-7219] 
remains to upgrade this iron ore is acid leaching likewise most of the advanced countries where successful dephosphorization through chemical method has been achieved. The methods other than acid leaching like bioleaching [5], roasting and melting separation [6], roasting followed by magnetic separation, and selective agglomeration plus reverse flotation [7] may be effective route to desulphurize the ore. Nevertheless, these methods are much costly, therefore for Dilband iron ore acid leaching [8-9] was selected. The selectivity and efficiency of the $\mathrm{HCl}, \mathrm{HNO}_{3}$ and $\mathrm{H}_{2} \mathrm{SO}_{4}$ leachants was studied and effective particle size, leaching time and leachant dose was evaluated.

\section{EXPERIMENTAL WORK}

Dilband iron ore sample of different particle size fractions were received from PSM. The practical size and elemental analysis of the samples is given in Table 1 .

For leaching experiments the iron ore of mass $5 \mathrm{gm}$ was mixed with $50 \mathrm{ml}$ of diluted acid in $100 \mathrm{ml}$ Pyrex cylinder. Then contents of cylinder were agitated using magnetic stirrer for time interval of 15, 30, 45 and 60 minutes at room temperature. Thereafter, leachates were separated using $5 \mu \mathrm{m}$ Whitman filter paper. This was followed by rinsing of ore residue with distilled water and drying for overnight at $100^{\circ} \mathrm{C}$. Finally, $\mathrm{Fe}, \mathrm{Ca}$ and $\mathrm{Al}$ were analyzed by using atomic PerkinElmer AA700 AAS (Absorption Spectrometer), whereas phosphorous content in leachate was determined by DR. 2000 spectrophotometer. SEM was used to study the perforations in the residue caused by leaching. The $\mathrm{pH}$ of the slurry before and after the addition of acids was $6.8 \pm 0.5$ and $2.5 \pm 0.8$.

\section{RESULT AND DISCUSSIONS}

\subsection{Effect of Size on Dephosporization}

To study the effective particle size, dephosphorization experiments were carried out in which $-600+212,-212+106$, and $-106 \mu \mathrm{m}$ size fraction were leached in $1 \% \mathrm{H}_{2} \mathrm{SO}_{4}$ solution for $30 \mathrm{~min}$ at ambient temperature. The percent extraction of $\mathrm{P}, \mathrm{Fe}, \mathrm{Ca}$ and $\mathrm{Al}$ shown in Fig. 1 indicates that dephosphorization achieved in $-600+212,-212+106$ and $-106 \mu \mathrm{m}$ particle size fractions was $49.5 \%, 55.6$ and $82.2 \%$, respectively. The increasing trend of dephosphorization with decreasing the particles size can be attributed with increase in the liberation of flourapatite mineral. Thus, inadequate liberation of flourapatite in $600+212$ and $-212+106 \mu \mathrm{m}$ particle size fractions reduced the reactivity of $\mathrm{H}_{2} \mathrm{SO}_{4}$ with phosphorous and resulted with sufficient extraction of Fe. The excess leaching of $\mathrm{Ca}$ in all size fractions further suggested that majority of flourapatite grains is distributed in the calcite matrix. This is in agreement with the findings of Abro et. al. [1] that fluoraptite is widely distributed in calcite rich biosparite iron stones.

\subsection{Effect of Leachant Type and Concentration}

The leaching behavior of $-106 \mu \mathrm{m}$ size fraction at ambient conditions for 30 minutes was further studied in $\mathrm{HCl}$, $\mathrm{HNO}_{3}$ and $\mathrm{H}_{2} \mathrm{SO}_{4}$. The $\mathrm{P}, \mathrm{Fe}, \mathrm{Ca}$, and $\mathrm{Al}$ leaching tendency of $\mathrm{H}_{2} \mathrm{SO}_{4}, \mathrm{HNO}_{3}$ and $\mathrm{HCl}$ at different concentration is plotted in Figs. 2-5. Results shown in Fig. 2 indicates that at $1 \%$ concentration of $\mathrm{HCl}, \mathrm{HNO}_{3}$ and $\mathrm{H}_{2} \mathrm{SO}_{4}$ the phosphorous removal was about 7, 29,

TABLE 1. PRACTICAL SIZE AND ELEMENTAL ANALYSIS OF SAMPLES

\begin{tabular}{|c|c|c|c|c|c|}
\hline Sample Size $(\mu \mathrm{m})$ & $\mathrm{P}(\%)$ & $\mathrm{Fe}(\%)$ & $\mathrm{Si}(\%)$ & $\mathrm{Al}(\%)$ & 3.61 \\
\hline$-600+212$ & 0.38 & 39.23 & 19.75 & 3.36 & 4.08 \\
\hline$-212+106$ & 0.27 & 38.12 & 19.76 & 3.19 & 7.93 \\
\hline-106 & 0.45 & 38.15 & 22.84 & 9.36 \\
\hline
\end{tabular}

Mehran University Research Journal of Engineering \& Technology, Volume 36, No. 3, July, 2017 [p-ISSN: 0254-7821, e-ISSN: 2413-7219] 
and $82.2 \%$ respectively. By increasing the dose of the acids up to $3 \%$ the desulphurization in case of $\mathrm{HCl}$ and $\mathrm{HNO}_{3}$ was reached to 68.9 and $77.8 \%$ respectively, whereas in case of $\mathrm{H}_{2} \mathrm{SO}_{4}$ marginal variation in \% removal of phosphorous was noted. The desulphurization trend represented by Fig. 2 clearly demonstrate that $\mathrm{H}_{2} \mathrm{SO}_{4}$ was more effective than other acids. In order to know whether $\mathrm{H}_{2} \mathrm{SO}_{4}$ is also selective as it has been reported in the literature [8-9], the leaching rate of $\mathrm{Ca}, \mathrm{Fe}$ and $\mathrm{Al}$ was evaluated. Fig. 3 indicates that leaching rate of $\mathrm{Ca}$ was appreciably low in case of $\mathrm{H}_{2} \mathrm{SO}_{4}$ as compared to $\mathrm{HCl}$ and $\mathrm{HNO}_{3}$, whereas leaching of $\mathrm{Fe}$ and $\mathrm{Al}$, shown in Figs. 4-5 respectively, was almost equivalent in all acids. The excess leaching of $\mathrm{Ca}$ with $\mathrm{HCl}$ and $\mathrm{HNO}_{3}$ as compared to $\mathrm{H}_{2} \mathrm{SO}_{4}$ is the additional witness from which it was substantiated that $\mathrm{H}_{2} \mathrm{SO}_{4}$ is also more selective to extract phosphorous as compared to counterpart $\mathrm{HCl}$ and $\mathrm{HNO}_{3}$ acids.

The above data make it obvious that $\mathrm{H}_{2} \mathrm{SO}_{4}$ has responded ideally for phosphorus extraction from iron ore. The selective extraction of phosphorous by $\mathrm{H}_{2} \mathrm{SO}_{4}$ can be explained by considering the number and nature of negative and positive ions (e.g. $\mathrm{SO}_{4}^{-2}, \mathrm{NO}_{3}$-Cl- and $\mathrm{H}^{+}$) produced by the acids and their affinity for $\mathrm{Ca}^{+2}$

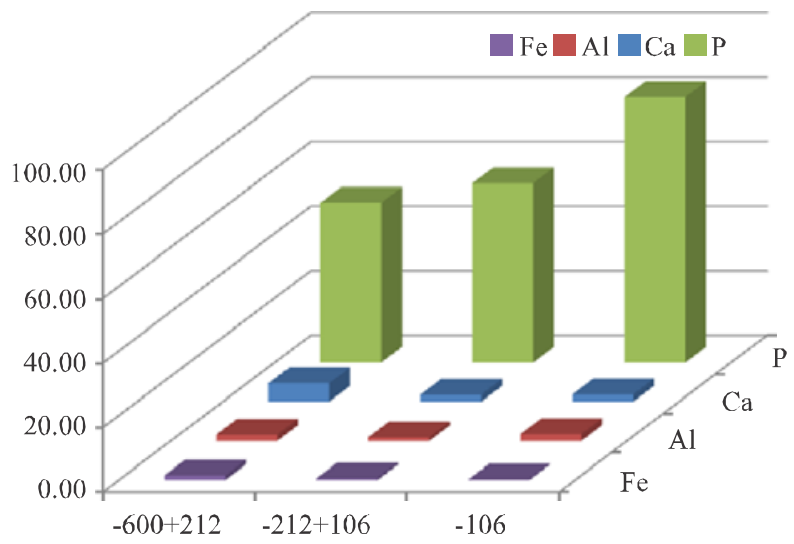

FIG. 1. EFFECT OF PARTICLE SIZE ON \% LEACHING OF P, $\mathrm{Fe}$, Ca, AND Al USING 1\% $\mathrm{H}_{2} \mathrm{SO}_{4}$ FOR 30 MIN AT ROOM TEMPERATURE cations present in flourapatite mineral $\left[\mathrm{Ca}_{5}\left(\mathrm{PO}_{4}\right)_{3} \mathrm{~F}\right]$. It is reported that $\mathrm{SO}_{4}^{-2}$ released from $\mathrm{H}_{2} \mathrm{SO}_{4}$ possess higher affinity with $\mathrm{Ca}^{+2}$ cations as compared to $\mathrm{Cl}^{-}$, and $\mathrm{NO}_{3}{ }_{3}^{-}$ species released from $\mathrm{HCl}$ and $\mathrm{HNO}_{3}$. Yong-Shi et. al. [8] and Cheng et. al. [10] have also observed that $\mathrm{H}_{2} \mathrm{SO}_{4}$ is preferentially reacting with phosphorous bearing mineral. Keeping in view the ideal response of $\mathrm{H}_{2} \mathrm{SO}_{4}$ an attempt was made to assess the leachability of leachant obtained from first set of experiment. It was noted that

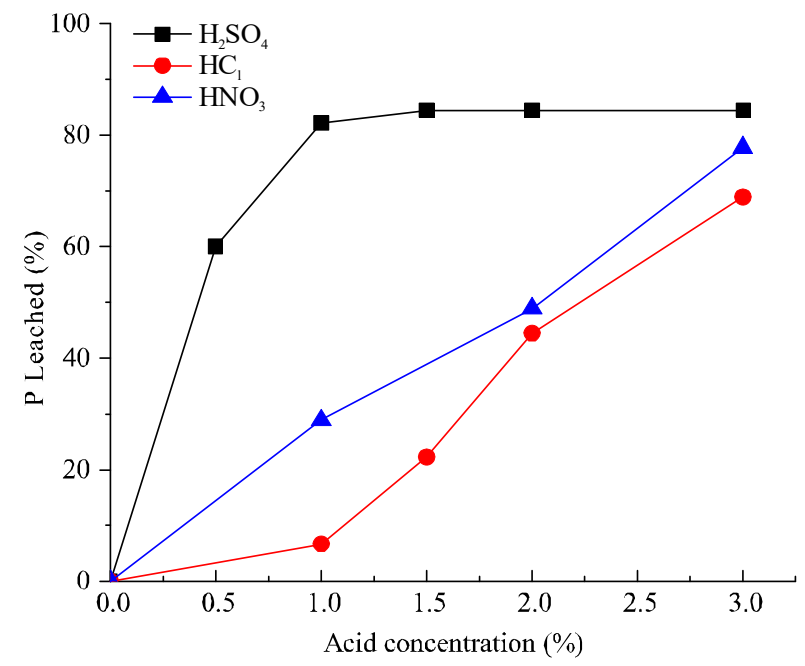

FIG. 2. EFFECT OF ACID TYPE AND CONCENTRATION ON LEACHING OF P PRESENT IN DILBAND IRON ORE

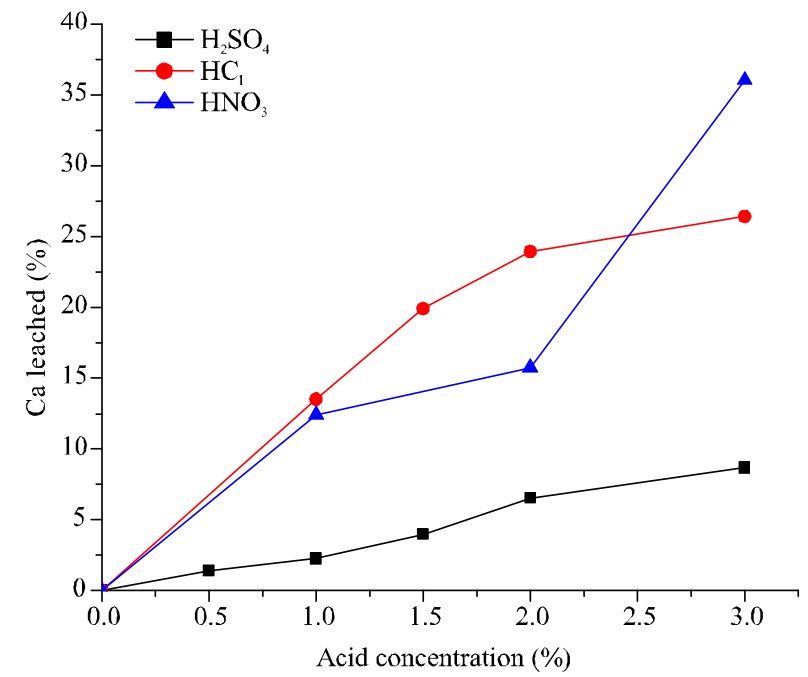

FIG. 3. EFFECT OF ACID TYPE AND CONCENTRATION ON LEACHING OF Ca PRESENT IN DILBAND IRON ORE

Mehran University Research Journal of Engineering \& Technology, Volume 36, No. 3, July, 2017 [p-ISSN: 0254-7821, e-ISSN: 2413-7219] 
by recycling the leachant of $\mathrm{H}_{2} \mathrm{SO}_{4}$ hardely $20 \%$ desulphurization was achieved.

\subsection{Effect of Leaching Time}

Effects of the leaching time on dephosphorization isshown in Fig. 6 which indicates that the percent extraction of phosphorous in case of $\mathrm{H}_{2} \mathrm{SO}_{4}$ remained dominate irrespective of leaching time. Moreover, from the results shown in Fig. 6 it can be substantiated that

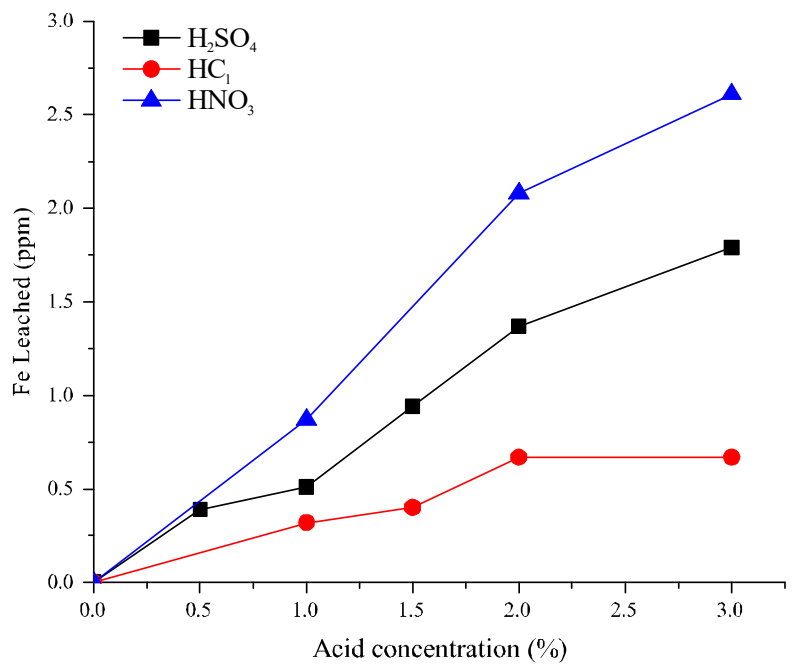

FIG. 4. EFFECT OF ACID TYPE AND CONCENTRATION ON LEACHING OF Fe PRESENT IN DILBAND IRON ORE

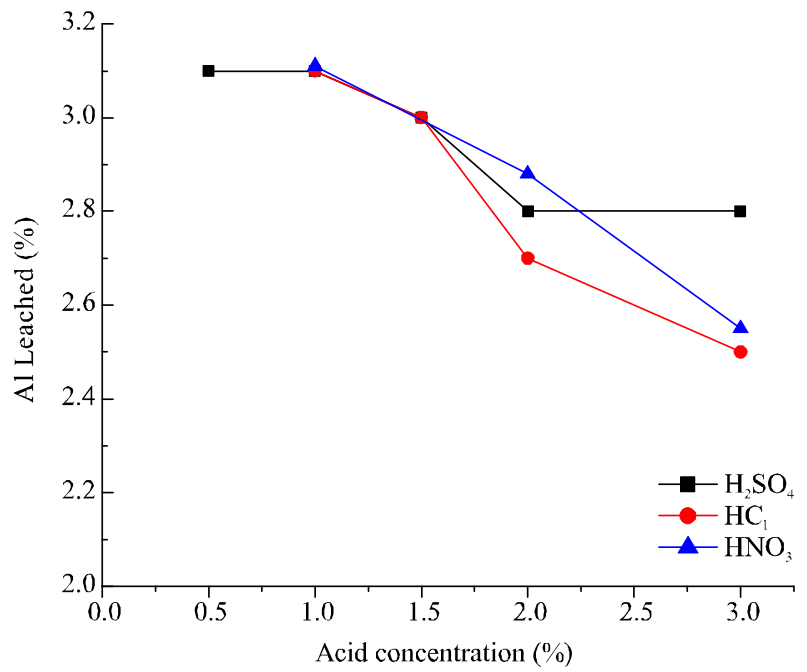

FIG. 5. EFFECT OF ACID TYPE AND CONCENTRATION ON LEACHING OF Al PRESENT IN DILBAND IRON ORE
30 min time is sufficient to leach out more than $82 \%$ poshourous from the ore matrix by using $1 \%$ concentrated $\mathrm{H}_{2} \mathrm{SO}_{4}$. In addition, Figs. 7-8 representing the effect of leaching time on the percent removal of $\mathrm{Ca}$ and Fe respectively clearly demonstrate that leaching time should not be prolong than $30 \mathrm{~min}$, otherwise sufficient amount of $\mathrm{Ca}$ and Fe will extract due to which selective dephosphorization will be affected.

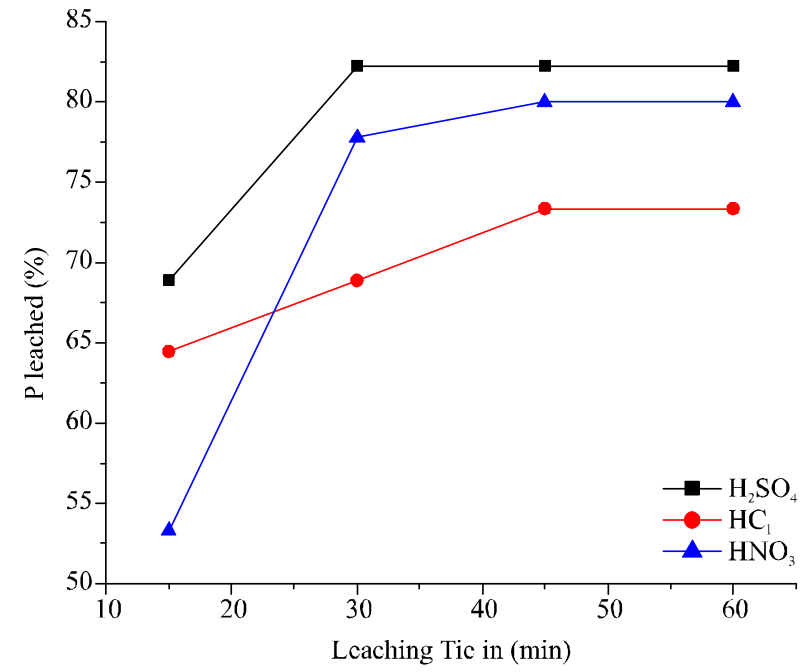

FIG. 6. EFFECT OF LEACHING TIME ON LEACHING OF P PRESENTIN DILBAND IRON ORE

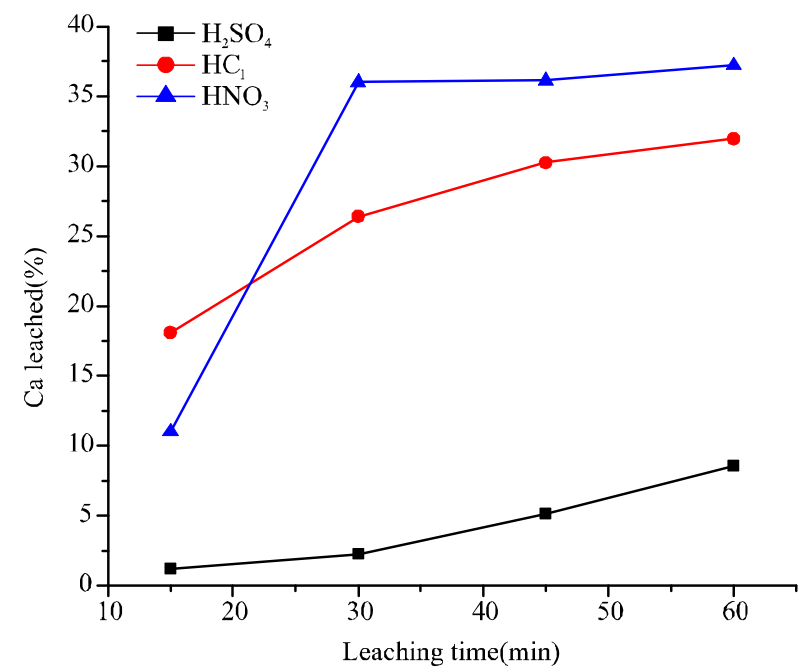

FIG. 7. EFFECT OF LEACHING TIME ON LEACHING OF Ca PRESENT IN DILBAND IRON ORE

Mehran University Research Journal of Engineering \& Technology, Volume 36, No. 3, July, 2017 [p-ISSN: 0254-7821, e-ISSN: 2413-7219] 


\subsection{Perforation Study}

In order to witness the selective leaching of flourapatite mineral with $\mathrm{H}_{2} \mathrm{SO}_{4}$ as compared to $\mathrm{HNO}_{3}$ and $\mathrm{HCl}$ acids perforation evidences were collected by illuminating the ore residue under SEM. Fig. 9(a-c) shows the SEM images of the ore residue collected after leaching experiments. By comparing the deepness and wideness features of the perforations it can be comprehended that perforations caused by $\mathrm{H}_{2} \mathrm{SO}_{4}$ are more detailed than caused by $\mathrm{HNO}_{3}$ and $\mathrm{HCl}$. From this, it can be substantiated that $\mathrm{H}_{2} \mathrm{SO}_{4}$ was more effective and selective to react with phosphorous bearing mineral than other minerals present in the ore body.

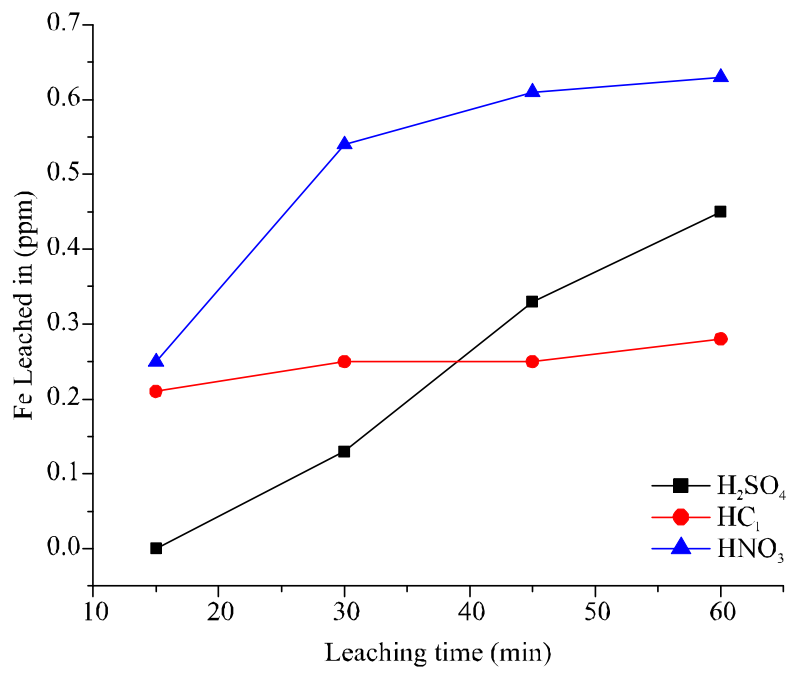

FIG. 8. EFFECT OF LEACHING TIME ON LEACHING OF FEPRESENT IN DILBAND IRON ORE

\section{CONCLUSION}

Present study concluded that percent removal of phosphorous from the ore body using $\mathrm{H}_{2} \mathrm{SO}_{4}$ is more selective and effective than $\mathrm{HCl}$ and $\mathrm{HNO}_{3}$ acids. While evaluating the effective size it was noted that at $1 \% \mathrm{H}_{2} \mathrm{SO}_{4}$ the $49.5,55.6$ and $82.2 \%$ dephosphorization was achieved in $-600+212,-212+106$, and $-106 \mu \mathrm{m}$ particle size fractions respectively, which meant that leaching rate of mineral is increasing with decrease in size. From this, it was conceived that leaching rate increase with increase in the liberation of flourapatite from host ore.

\section{ACKNOWLEDGMENTS}

The authors greatly acknowledge the authority of Mehran University of Engineering \& Technology, Jamshoro, Pakistan, for their cooperation in providing the lab facilities for conducting the experimental work. Authors also wish to thank the Organizing Committee of $2^{\text {nd }}$ National Conference on Metallurgy and Materials, for priving the platform for oral presentation and publishing the paper in Mehran University Research Journal of Engineering \& Technology.

\section{REFERENCES}

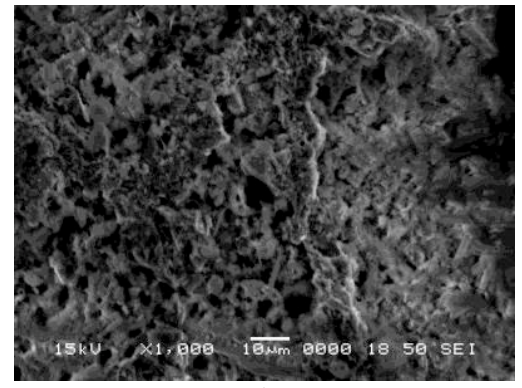

A

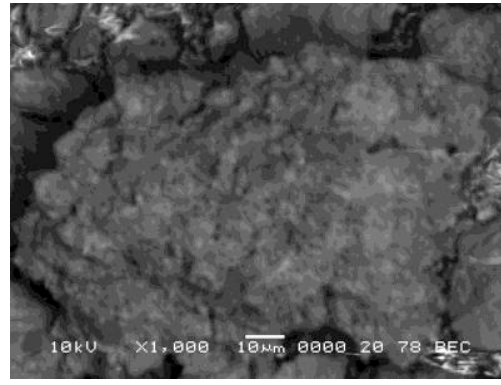

B

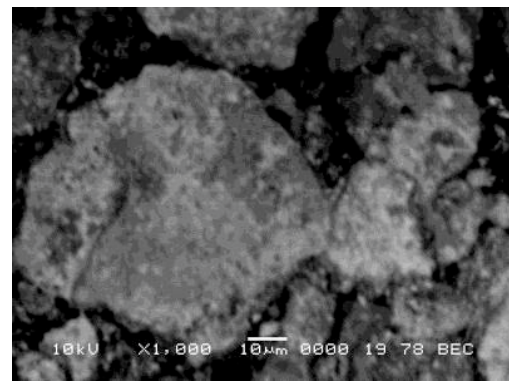

C

FIG. 9. SEM IMAGES INDICATING PERFORATION IN DILBAND IRON ORE SAMPLES 
[2] Abro, M.I., Pathan, A.G., Mallah, A.H., and Böhm, A., “ 'Mineralogical Characterization of Dilband Iron Ore Deposits of Balochistan, Pakistan [Mineralogische Beschreibung der Dilband-Eisenerzlagerstätten in Balochistan, Pakistan]", BHM Berg-und Hüttenmännische Monatshefte, Springer Wien Publisher Volume 153 No. 6, pp. 206-210, June, 2008.

Abro, M.I., Pathan, A.G., and Mallah, A.H., "Liberation of OoliticHematite Grains from Iron Ore, Dilband Mines Pakistan”, Mehran University Research Journal of Engineering Technology, Volume 30, No. 2, pp. 329-338, Jamshoro, Pakistan, April, 2011.

Abro, M.I., Pathan, A.G., and Mallah, A.H., "Work Index and Grinding Energy Assessment of Dilband Iron Ore, Pakistan", Mehran University Research Journal of Engineering Technology, Volume 30, No. 1, pp. 29-34, Jamshoro, Pakistan, January, 2011.

Delvasto, P., Valverde, A., Ballester, A., Munoz, J., González, F., Blázquez, M., Igual,J., and García-Balboa, C., "Diversity and Activity of Phosphate Bioleaching Bacteria from a High-Phosphorus Iron Ore", Hydrometallurgy, Volume 92, No. 3, pp. 124-129, 2008.
[6] Hui-Qing, T., Zhan-Cheng, G., and Zhi-Long, Z., "Phosphorus Removal of High Phosphorus Iron Ore by Gas-Based Reduction and Melt Separation", International Journal of Iron and Steel Research,Volume 17, No. 9, pp. 1-6, 2010.

[7] Jun, J., "Study on Dephosphorization Technology for High-Phosphorus, Iron Ore", Mining Metallurgy, Volume 12, No. 2, pp. 32-37, 2003.

[8] Yong-Shi, J., Tao, J., Yong-Bin, Y., Qian, L., Guang-Hui, L., and Yu-Feng, G., "Removal of Phosphorous from Iron Ores by Chemical Leaching", Journal of Central South University Technology, Volume 13, No. 6, pp. 673-677, 2006.

[9] Maitlo, I., "Dephosphorization of Dilband Iron Ore By Hydro-Metallurgical Process", ME Thesis, Mehran University of Engineering \& Technology, Jamshoro, Pakistan, June, 2013.

[10] Cheng, C.Y., Mishra, V.N., Clough, J., and Mun, R., "Dephosphorisation of Western Australian Iron Ore by Hydrometallugical Process", Minerals Engineering, Volume 12, No. 9, pp. 1083-1093, 1999. 